\title{
Na Primeira Margem do Rio:Território e Ecologia do Povo Xavante de Wedezé
}

\author{
James R. Welch, Ricardo Ventura Santos, Nancy M. Flowers, and Carlos E.A. Coimbra Jr. 2013. Museu do Índio/ \\ FUNAI, Rio de Janeiro. Pp. 244. ISBN 978-85-85986-46-9.
}

Reviewed by Nicholas Kawa

Reviewer address: Department of Anthropology, Burkhardt Building Room 315, Ball State University, Muncie, Indiana 47306. nckawa@bsu.edu

As Brazil's demands for energy, resources, and infrastructure expand, indigenous peoples of the nation are facing greater pressure on their lands, and in some cases, even open abuses of their rights. Fortunately, this book highlights an important case study in which advances have been made by indigenous peoples and the researchers who work alongside them to establish claims to traditional lands. This text is the outgrowth of a broader project that was designed to identify and demarcate the Wedezé indigenous territory of the Xavante people in the state of Mato Grosso, Brazil. As described in the introduction, the book also carries the objective of disseminating historical, anthropological, and ethno-ecological knowledge of the Xavante.

The book is organized into a simple structure with chapters that discuss Xavante language and history, demographics, environmental context, economic and subsistence activities, use of flora and fauna, sacred and ceremonial spaces, and Wedezé's demarcation as an indigenous territory. The introduction explains that the title of the book (in English: "On the First Bank of the River: Territory and Ecology of the Xavante People of Wedezé") refers to the Xavante's first community established on the east bank of the Rio das Mortes in the $19^{\text {th }}$ century. Although the Pimentel Barbosa indigenous territory was later established on the west bank of the River, Wedezé was not officially recognized despite the extended history of occupation and use by the Xavante. Now, with a growing population in the area totaling around 1500 people, the authors explain why the establishment of the Wedezé indigenous territory is very much needed.
Chapter two provides a basic background on scholarly work on the Xavante language and social structure. This chapter is also the most important for contextualizing the establishment of Xavante villages in Wedezé during the colonial period. The authors give an extended account of settlement, displacement, and resettlement from the late $19^{\text {th }}$ century up to the present, drawing on archival materials and oral histories. At times, the historical discussion is somewhat difficult to follow, but this simply reflects the complex history of movement and resettlement rather than any shortcomings of the authors' discussion of such events. In many ways, this detailed account is fundamental to the authors' claims that the occupation of Wedezé has been continuous over long stretches of time since the arrival of non-indigenous peoples to the region.

The third chapter focuses on demographics, which is also critical for understanding the Xavante's relationship to the Wedezé territory. In all the communities currently in Pimentel Barbosa and Wedezé, over $50 \%$ of the population is under 15 years of age. And of the nine indigenous territories where the Xavante reside, Pimentel Barbosa had the highest growth rates between 1999 and 2004. This explains why the neighboring territory of Wedezé is crucial for accommodating their growing population.

Chapters four, five, and six are likely to be of greatest interest to ethnobiologists. These chapters discuss the environmental context and subsistence activities of the Xavante as well as their use of the local flora and fauna. Here the authors provide extended discussion of the Xavante relationship to the cerrado (scrub savanna) environment, which is current- 
ly threatened by the expansion of soy agribusiness and cattle ranching. Many important notes about the historical ecological relationships of the Xavante to the landscape are highlighted in these chapters, including the existence and management of anthropogenic forests that harbor high concentrations of useful plants. The authors also examine in detail the use of fire in hunting and its specific ecological role in the management of the cerrado. These forms of landscape management are the product of Xavante subsistence activities rooted in a deep history, and the authors argue that the continuation of these activities is fundamental to Xavante socio-cultural identity. However, the book also addresses how the Xavante have adapted and responded to economic change, including development projects in the 1970s that attempted to push the industrial agricultural model on the Xavante for production of rice.

Chapter six is dedicated specifically to Xavante use of plants and animals. Many useful plants species are described and presented in this section, but the authors explain that restrictions prevent them from discussing medicinal or spiritual plants since knowledge of these is considered secret cultural or intellectual property. They do note, however, that the Wedezé territory is an important source of such plants, including many that are considered rare or non -existent in neighboring Pimentel Barbosa. Yet even considering such limitations, as a reader I was left craving more specifics on Xavante ethnobotany and ethnozoology. Perhaps we can hope for a future book on Xavante ethnobiology, which would surely be of great value to all. Many of the chapters would've also benefited from the inclusion of more Xavante voices. Some come out in the discussion of ceremonies and sacred spaces in chapter seven, but more direct Xavante insights would've enriched many of the other chapters as well.

In conclusion, this book serves as an important example of how a project report for identifying and demarcating indigenous lands can be made into an accessible document of great public value, and for this the authors should be commended. The large, colorful photographs and numerous useful maps and tables also provide excellent visual support. Future research should benefit from this text and hopefully expand upon this model, perhaps incorporating more indigenous voices into the narrative. Also since this book is written in Portuguese, it highlights the need for similar texts in other national languages that may serve to broaden awareness of indigenous land rights.
Clearly, if agro-industrial development continues on its current path, indigenous territories like Wedezé will stand as some of the most important biological and cultural refuges on Earth. 